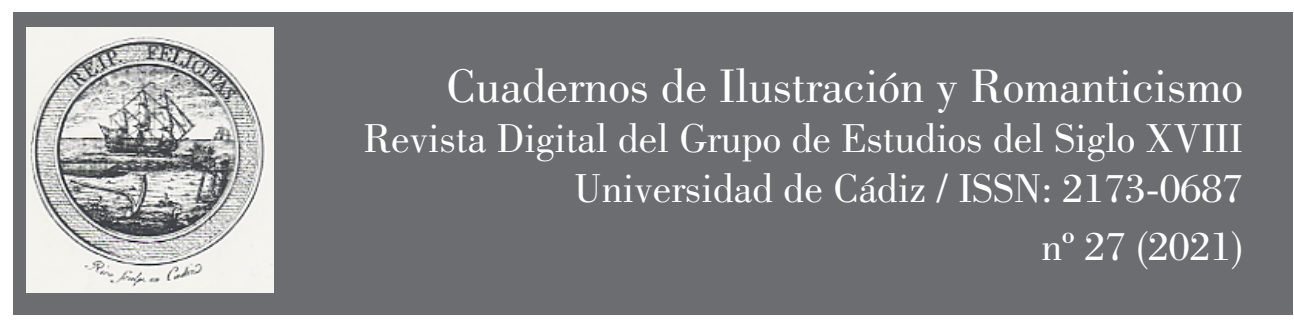

\title{
LA INTERSECGIÓN DE GATEGORÍAS MARGINADAS EN EL TEATRO ESPAÑOL DEL SIGLO XVIII: ACTRICES Y DRAMATURGAS
}

\author{
María del Carmen Amaya Macías \\ (Universidad de Cádiz) \\ https://orcid.org/0000-0003-2303-7861
}

Recibido: 26-02-2021 / Revisado: 04-05-2021

Aceptado: 24-04-2021 / Publicado: 18-12-2021

REsumen: Dentro de las dramaturgas dieciochescas que conocemos y cuyos textos conservamos existe una cierta variedad en cuanto a sus procedencias sociales. En este trabajo abordamos la obra de aquellas mujeres que, además de dramaturgas, fueron actrices, con el propósito de dilucidar las posibles resonancias que estas intersecciones pudieron tener en la producción de sus piezas teatrales. Para ello, contamos con un análisis de las obras Las mujeres solas, de Mariana Cabañas, y La visita del hospital del mundo, de Mariana Alcázar. Dicho análisis viene precedido de estudio acerca del contexto social y cultural que rodea las profesiones de sendas autoras.

Palabras Clave: Mariana Cabañas, Mariana Alcázar, actriz, dramaturga, siglo XVIII, sainete.

THE INTERSECTION OF MARGINALISED CATEGORIES IN EIGHTEENTH-CENTURY SPANISH DRAMA: ACTRESSES AND PLAYWRIGHTS

ABSTRACT: There exists some variety in terms of social background among the Spanish women playwrights of the eighteenth-century whose texts are known and preserved. In this paper we approach the works of these women who were actresses as well as playwrights. It is our aim to elucidate the possible influence these intersections could have exerted on their dramatical production. In order to achieve our goal we analyse the works Las mujeres solas, by Mariana Cabañas, and La visita del hospital del mundo, by Mariana Alcázar. We also include a previous study about the social and cultural context surrounding the professional development of both female authors.

KEYwords: Mariana Cabañas, Mariana Alcázar, actress, female playwright, $18^{\text {th }}$-century, sainete. 


\section{INTRODUCCIÓN}

Desde hace varias décadas las investigaciones sobre la presencia de las mujeres y su papel en la sociedad del siglo XviII han gozado de gran interés. Esto ha supuesto un aumento considerable del número de trabajos tanto sobre cuestiones generales como en torno a figuras concretas, cuyas vidas y obras se desarrollaron al abrigo de los cambios que trajo consigo la Ilustración. Este trabajo pretende contribuir en tal línea centrándose, en este caso, en la producción teatral de dos mujeres: Mariana Cabañas y Mariana Alcázar Peña.

El interés de la obra de estas dramaturgas reside precisamente en la intersección ${ }^{\mathrm{I}}$ de categorías marginales que las atraviesan por el hecho ser además de escritoras, actrices durante un siglo que experimentó grandes cambios y cuyo impacto resultó decisivo en la Historia de las mujeres. Igualmente, María Laborda, conocida artísticamente como Margarita Castro, reúne estas características. No obstante, optamos por dejar su obra, La dama misterio, capitán marino, fuera de nuestro trabajo por razones de adecuación y discrimen del corpus. Así, mientras que las dos primeras se adscriben al género del sainete; la tercera escribe una comedia que, si bien no es neoclásica, está más cerca de la comedia sentimental y, por tanto, presenta unas particularidades distintas propias del género en el que se inserta. Asimismo, tampoco incluimos en nuestro análisis la producción dramática escrita por Joaquina Comella Bermeyón pues, aunque esta autora a priori parte de un contexto cultural muy similar al de Alcázar, Cabañas y Laborda, ${ }^{2}$ no tenemos datos que demuestren su vinculación al teatro como actriz.

Nuestro objetivo es analizar las piezas teatrales de estas dos escritoras en búsqueda de posibles características comunes que pongan de manifiesto su peculiaridad con respecto a aquellas mujeres que empuñaban la pluma desde categorías sociales sino privilegiadas, al menos distintas a la de estas. En esta línea, nuestro análisis del corpus ha de ser necesariamente comparativo. No obstante, consideramos que todo investigador que desee adentrarse en la producción científica o literaria de las escritoras pertenecientes al siglo XVIII debe no solo conocer la situación de estas en su contexto histórico, sino también actualizar el prisma de análisis de su caudal creativo desde una visión comprometida con los conceptos de género y revisión del canon.

Un análisis complejo, actual y que satisfaga las necesidades científicas de nuestra sociedad debe entrañar la profundización más allá de las perspectivas historicistas y biografistas no con el objetivo de eliminar tales perspectivas, sino de cuestionar si estos enfoques resultan suficientes al aplicarlos al caso concreto de la escritura de las mujeres en el siglo XviII. Dichas perspectivas historicistas y biografistas son en un primer momento esenciales para el rescate de las autoras y sus obras. No obstante, profundizar en los textos de acuerdo con metodologías transversales a estas disciplinas nos parece el siguiente paso para continuar reevaluando estas obras de forma que ofrezcan fructíferas nuevas lecturas sobre la producción literaria de la época. El texto literario, pues, se construye no solo de acuerdo con los contenidos discursivos que operan en el contexto histórico-biográfico, sino también de acuerdo con la interpretación individual que cada una de estas escritoras aporta en su escritura:

I Aunque el término «interseccionalidad» se atribuye por primera vez a la investigadora afroamericana Kimberlé Crenshaw en su trabajo de 1989 , una de las principales académicas de la teoría de la interseccionalidad aplicada a los estudios feministas es Leslie McCall (2005). Esta disciplina analiza cómo las distintas categorías biológicas, sociales y culturales marginales —identidad género, raza, sexualidad, religión, etc. — interaccionan en diversos niveles formando un sistema de opresión que actúa discriminando al individuo en múltiples esferas.

2 Nos referimos con esta afirmación al hecho de que el conocimiento del que parte Joaquina Comella en la composición de su pieza teatral no es de tipo intelectual, sino que proviene más bien de un conocimiento práctico del funcionamiento del teatro en su época como desarrollaremos a lo largo de estas páginas. 
Las escritoras dieciochescas constituyen un ejemplo magnífico de cómo apuntar al centro desde los márgenes, un ejemplo del deseo voluntarioso de demostrar la pertenencia al sistema apuntalándolo desde su ortodoxia ideológica con los medios que se tienen al alcance. [...] La parte más interesante del estudio de la dramaturgia femenina del XviıI es, precisamente, la investigación y búsqueda de las grietas por las cuales la marginalidad de la dramaturga, su heterodoxia, su diferencialidad como mujer escritora, se filtran en su creación y por un momento descomponen ese cuadro perfecto de orden moral y social que dibuja el teatro ilustrado (Establier Pérez, 2006: 185).

Este análisis se nos antoja necesario para dar cuenta del hecho de que las mujeres en la Ilustración empiezan a tener acceso a esferas sociales anteriormente restringidas. Esto supone para ellas un revulsivo en cuanto a que desean contribuir en aquellos espacios que les estaban vedados, al tiempo que evitaban transgredir de forma explícita las normas que rigen la sociedad en la medida de lo posible.

Considerando las peculiaridades de nuestro objeto de estudio acompañamos, pues, el análisis comparativo de los textos con un recorrido - necesariamente somero por razones de espacio - por el siglo Xviı en una doble vertiente que ilumine cuáles eran las condiciones de vida y los obstáculos que encuentran las escritoras y las actrices - intersección en la que se hallan nuestras autoras - en el desarrollo de estos trabajos que apenas comienza a contemplarse como profesiones, con todo lo que esto implica.

\section{LAS MUJERES COMO ESCRITORAS}

Varios y estrechamente interrelacionados son los factores que contribuyen al creciente aumento de la presencia de las mujeres en los círculos intelectuales de la sociedad española del período ilustrado: el impulso de la educación como motor del cambio que promueve la Ilustración, el afán de modernización de las naciones, así como los nuevos ámbitos de sociabilidad, que suponen un acercamiento en las relaciones entre hombres y mujeres tanto en el ámbito privado como en el público.

El ideario ilustrado trae consigo un cuestionamiento generalizado de las costumbres y las formas de vida de la sociedad. Tal y como Mónica Bolufer analiza en Mujeres y modernización: estrategias culturales y prácticas sociales (siglos XVIII-XX), el debate de los sexos y la «querella de las damas» que se inicia en la Edad Media —e irá actualizándose a lo largo de los siglos - se tomó a partir del siglo XviI como síntoma de modernidad o falta de ella. España se contempla en este momento como una nación poco civilizada por parte de la intelectualidad ilustrada francesa, que cifra su falta de avance precisamente en la inexistencia de una sociabilidad más abierta entre hombres y mujeres. Para combatir esta imagen de atraso cultural, el país se esforzó por favorecer las nuevas formas de sociabilidad mixta, ${ }^{3}$ en la que las mujeres no eran solo sujetos pasivos, sino que se convirtieron en el centro de la interacción, dirigiendo —al menos, teóricamente — ${ }^{4}$ salones y tertulias literarias, en ocasiones en sus propias residencias. En estos espacios de intercambio intelectual —en parte reflejo de la adopción de costumbres extranjeras, en parte herencia de

3 Para una ampliación y actualización sobre este aspecto de la sociedad dieciochesca — ampliamente tratado en el pionero trabajo de Martín Gaite (1972) — vid. Bolufer (2014b) y Cantos Casenave (2009).

4 Existe una gran diferencia entre el papel que las mujeres españolas desempeñan en estos nuevos espacios de civilidad con respecto a las salonières, herederas de las précieuses. Habitualmente, las españolas cumplen la función de amenizar y hacer más atractiva la reunión, mientras que las francesas sí tuvieron una decidida influencia en la sociedad. Franco Rubio (2007) y Bolufer (2014b). 
costumbres ya arraigadas en el Barroco- las mujeres tenían un papel importante. No obstante, pronto se evidenció tanto la falta de instrucción como de conocimiento de las normas de sociabilidad de las españolas en la incapacidad inicial con la que estas afrontan su recién adquirido papel de anfitrionas en el nuevo paradigma de relaciones sociales.

Estos nuevos espacios y el papel de las mujeres en ellos arrastraron al centro del debate la necesidad de cambios en la educación de las mujeres para garantizar el progreso y la felicidad de la Nación. Sobre este tema se creó no solo un debate, sino un subgénero propio en los escritos pedagógicos. Mientras que la educación de las clases bajas y asalariadas no presentaba ninguna complicación — reducida a cuestiones básicas dirigidas al trabajo, la obediencia y la moral cristiana-, el caso de las mujeres de clases media y alta era cuestión distinta. Numerosos textos de todo tipo fueron publicados en torno a esta cuestión y se hizo hincapié en que la nueva educación ilustrada pensada para las mujeres debía prepararlas para cumplir sus funciones según las nuevas costumbres de civilidad sin descuidar sus otras labores. ${ }^{5}$

Sin embargo, la publicación de Emilio, o de la Educación (1762) de Jean-Jacques Rousseau no hizo sino poner de manifiesto que el modelo educativo femenino - representado por Sofía - lejos estaba de suponer una igualdad entre hombres y mujeres, pues venía a remontarse a los viejos discursos sobre la inferioridad del género femenino y su distinta «naturaleza», sentimental y delicada. El pensamiento rousseauniano tuvo gran influencia en sus coetáneos y llevó a escritoras como Josefa Amar y Borbón a reivindicar la necesidad de una educación femenina, no obstante, limitada en cuanto a su alcance. ${ }^{6}$ Los cimientos del proyecto ilustrado comenzaron a desdibujarse y emergieron, a su vez, las contradicciones y desequilibrios de la Ilustración en lo que a las mujeres y su estatus en la sociedad se refería. Si bien este discurso abogaba por una mejora en la situación de las mujeres, no dudaba asimismo en volver a relegarlas a un segundo plano que perpetuara la desigualdad de géneros, cambiando el discurso tradicional de la inferioridad del género femenino por uno que partía de la complementariedad de esta con respecto a los hombres:

Las ambigüedades y limitaciones de los escritos educativos, los proyectas y las realizaciones ponen de manifiesto cómo, pese a los proclamados propósitos de remediar la «ignorancia» de las mujeres, las propuestas iban básicamente orientadas a formarlas para un rol doméstico y social redefinido: el de esposas y madres entregadas y, en todo caso, mujeres capaces de satisfacer las obligaciones de la sociabilidad. Espíritu utilitario que contrasta con el modo en que muchas mujeres concebían su propia educación, como una puerta abierta al saber y un motivo de íntima satisfacción (Bolufer, 2006: 280-28I).

Aunque este avance se mostrara insuficiente para las mujeres, se creó en la sociedad del XVIII un ambiente mucho más propicio para la incursión de estas en el mundo literario. Así, nacieron toda una serie de publicaciones que dirigieron su atención especialmente a ellas, con el consecuente aumento de suscriptoras. La imagen de la mujer lectora se comercializó y no resulta extraño que aparecieran numerosos grabados y obras literarias que las retratan leyendo (Urzainqui, 2006a y 2016; y Bolufer, 2008: I35-I36). En este contexto,

5 «Por ello, los nuevos programas educativos incluyen, además de doctrina y "labores de manos" (éstas con un sentido más simbólico que práctico para mujeres acomodadas), higiene y economía doméstica, normas de civilidad para la vida social y una formación intelectual algo más amplia y variada que antaño, aunque limitada en extensión y profundidad: nociones de geografía e historia, a veces lenguas extranjeras o rudimentos de las ciencias» (Bolufer, 2005: 486).

6 Esta escritora denuncia la situación educativa de las mujeres en su «Discurso sobre la Educación física y moral de las mujeres» (I786). Sin embargo, en su análisis la educación femenina tiene un propósito utilitarista, cuyo objetivo es cumplir con su nuevo papel social. Su reforma educativa perpetúa el status quo, pues sigue encasillando a la mujer y negando su entrada masiva a círculos intelectuales como las universidades (Franco Rubio, 2007). 
para la prensa las mujeres no solo formaban parte de esa masa de lectores a quienes había que formar, sino que, además, se convirtieron en el objetivo de ciertas publicaciones especializadas, sobre todo a partir de los años 70 , al convertirse en un sector en crecimiento. No obstante, si la valoración de las mujeres como receptoras era un fenómeno en boga, el aspecto creativo de la literatura entrañaba para ellas todavía ciertas dificultades:

$\mathrm{Y}$ es que escribir y publicar exige un cúmulo de condiciones, tanto externas como internas. Ante todo, una educación adecuada, pero también una cierta comodidad material, tiempo y dedicación y, asimismo, no como condición indispensable, pero sí propiciatoria, algunos contactos, relaciones e influencias, útiles a la hora de afrontar la negociación con la imprenta, la financiación de la obra y los trámites con la censura. Pero también requiere cierta determinación y seguridad personal: el deseo de escribir, el sentimiento de la propia capacidad y la voluntad de intervenir en la esfera de la opinión pública a través de la publicación (Bolufer, 2009: 164-165).

Como afirma Bolufer, las mujeres que se lanzaron a empuñar la pluma en el xviII no solo tenían que sortear el obstáculo de una educación utilitaria que no las preparaba para ser escritoras, sino que también debían superar la frontera de la falta de contactos de la red de mecenazgo propia del mundo de la publicación. ${ }^{7}$ Todo aquello sin olvidar el desprestigio social que conllevaba el descuido de su papel como madre y esposa para dedicarse a las letras. A menudo estas mujeres se asomaron a la escritura casi pidiendo permiso, alegando intereses de ocio más que deseos de fama, lo que explica el hecho de que hoy contemos con pocas ediciones y manuscritos de sus obras, tal y como explica García Garrosa. ${ }^{8}$ Asimismo, aquellas mujeres que mostraron un mayor interés por el saber fueron rápidamente masculinizadas o tachadas de «bachilleras», entre otros términos despectivos que señalaban la opinión generalizada de gran parte de la sociedad.

A pesar de todas las dificultades, el número de escritoras en el siglo XviII aumentó con respecto a siglos anteriores y el perfil de estas se diversificó. Las escritoras ya no son necesariamente eclesiásticas o aristócratas, ${ }^{9}$ sino que también se suman a estas mujeres «capas intermedias vinculadas al mundo de la hidalguía, las profesiones y cargos o la burguesía comercial de origen extranjero» (Bolufer, 2008: 138). Estas mujeres comparten, según han analizado varias investigadoras en los últimos años (Bolufer, 2008 y 2009; García Garrosa, 2007; López-Cordón, 2005 y 2006), una serie de características que facilitan su ejercicio como escritoras: pertenecieron a un contexto social abierto a las nuevas tendencias intelectuales y culturales, se desarrollaron en un ambiente familiar que les permitió recibir

7 «Todos concibieron todavía su práctica de escritura como un quehacer desinteresado porque sus recursos financieros dependían de otras fuentes, se beneficiaron de las ventajas del clientelismo y aprovecharon todo lo posible el mecenazgo de estado que se acrecienta y diversifica en el siglo xvin. Pero este complejo y eficaz engranaje, consustancial con la propia ideología ilustrada, fallaba cuando quien cogía la pluma era una mujer que carecía de caja de resonancia para difundir sus escritos, o de lo que todavía era más decisivo, recursos propios a la hora de publicar o de algún tipo de "premio" que les motivara a hacerlo» (López-Cordón, 2006: 384).

8 «Las mujeres escriben, según confiesan ellas mismas en ocasiones, por afición a las letras, por entretener ratos de ocio, por deseo íntimo de expresar sentimientos, por ejercitarse en la traducción de las lenguas que estudiaban, por tener una diversión literaria en una fiesta familiar o conventual. Componen poemas, textos dramáticos, novelas, traducciones, discursos, sin ánimo quizá de ver más luz que la de los círculos privados, y que sus propias autoras no pocas veces destruyen en un rasgo de pudor que al tiempo es el destino de lo ya concebido como efímero. Solo teniendo en cuenta este peculiar acceso de la mujer al terreno de las letras podemos entender por qué de las más de cien mujeres que tomaron la pluma en el xviII conocemos hoy una exigua obra impresa y por qué tampoco son numerosos los manuscritos con sus obras» (García Garrosa, 2004: 26).

9 En cuestión de porcentajes, Palacios Fernández (2002: 88) calcula el 66\% de las escritoras son laicas y solo el $33 \%$ pertenecen al estado eclesiástico. 
una educación más esmerada, tuvieron ciertos deseos de influir socialmente mediante sus escritos y se apoyaron en el ideario ilustrado en gran medida, no sin señalar las contradicciones y limitaciones del Siglo de las Luces con respecto a ellas:

No resulta sorprendente que estas mujeres compartieran en buena medida el lenguaje y el ideario ilustrado [...] Sin embargo, discrepan también con frecuencia de las ideas más extendidas en su época sobre la naturaleza y función social de su sexo. Y si se distancian de esos modelos, lo hacen, precisamente, desde actitudes ilustradas, revelando así las fisuras de un pensamiento y de unas prácticas sociales que consideran arbitrarias y caducas muchas de las ideas recibidas de la tradición, pero prolongan y renuevan buena parte de los prejuicios acerca de las mujeres (Bolufer, 2008: 143).

En este sentido, también Zorrozúa (1998) estableció en su tesis una clasificación de las escritoras del XviII en dos grandes grupos: aquellas que escribieron desde un discurso ilustrado y dentro de las características propias de la escritura femenina de la época (una escritura útil, sencilla y modesta sin mayores pretensiones de intelectualidad) y otras que rebasaron esas limitaciones, igualándose a cualquier otro escritor de la época en sus propósitos, formas y temas. Así, aunque entre las escritoras dieciochescas pareció existir una cierta predilección por la poesía y la traducción, así como por las obras de carácter moral o didáctico —en consonancia con el papel social que se les había asignado-, estas también trascendieron estos géneros, dedicándose, entre otros, al dramático. Las mujeres no solo fueron asiduas lectoras y espectadoras de los teatros, sino que también fueron agentes activos como cantantes, actrices y escritoras de piezas teatrales con mayor o menor fortuna (Palacios Fernández, 2000: 89; Vega Toscano, 2016: 299).

Si nos adentramos en el universo de la dramaturgia femenina, debemos observar una serie de condicionamientos que afectaban de manera general a toda la producción teatral del siglo XVIII. Esta se divide en dos grandes tendencias:

I. El teatro popular, que mantiene la estética barroca y cuyo fin principal es el entretenimiento y la obtención del favor del público.

2. El teatro neoclásico, surgido a mitad de siglo y basado en las reuniones de un grupo de intelectuales en torno a la Academia del Buen Gusto, cuyo texto fundacional es la Poética (1737) de Ignacio de Luzán. Este teatro juzga la calidad de las obras a partir del cumplimiento de las tres unidades aristotélicas (acción, tiempo y lugar), así como de la adecuación al decoro y el respeto a la verosimilitud.

Aunque Palacios Fernández (2006) afirma que las dramaturgas fluctuaron entre las dos tendencias en las mismas condiciones que sus compañeros, Establier Pérez (2006: I25) profundiza en esta división, estableciendo una diferencia de género que marca la adscripción a una u otra tendencia. Así, esta investigadora afirma que, salvo conocidas excepciones como María Rosa Gálvez, no fueron demasiadas las mujeres escritoras que escribieron tragedias o comedias neoclásicas, optando por la composición de obras de carácter popular: ${ }^{\mathrm{IO}}$

Io La tesis defendida por Establier Pérez si bien cierta en gran medida, puede ser matizada. Así, tal y como afirma García Garrosa (2004, 2007) las escritoras dieciochescas no solo están plenamente integradas en el panorama literario de su tiempo, sino que en no pocas ocasiones están a la vanguardia de muchos de sus compañeros. Es este el caso de María Rita de Berrenechea que, como han venido a demostrar los análisis recientes de sus obras Catalín (Urzainqui, 2006b) y La aya (García Garrosa, 2004) se adelantó a los presupuestos de la estética neoclásica de Iriarte y Moratín y que, además, fue la primera en cultivar la comedia sentimental en el ámbito del teatro español. También en esta estela se sitúa la obra de María Lorenza de los Ríos y Gracia de Olavide. 
[...] la mayor parte de la producción dramática femenina de esta época, casi toda ella por cierto de finales del XVIII y de la primera década del XIX, queda fuera de los modelos ortodoxos de la comedia o de la tragedia neoclásicas, y se adecúa mejor a la tradición popular, al modelo de la comedia barroca o a los nuevos cauces del género sentimental en boga en el cambio de siglo (Establier Pérez, 2006: 18I).

Según la autora, las razones que podrían aducirse son principalmente tres. La primera es la falta de instrucción de muchas de las mujeres en la materia literaria que era requerida para cumplir con el modelo neoclásico; la segunda, el peso que los discursos acerca de la inferioridad intelectual de las mujeres tenían para la sociedad en la recepción de los textos escritos por estas y, finalmente, la tercera causa reincide en la primera para añadir que, aun teniendo formación, muchos temas (véase el honor, el vicio, la infidelidad, etc.) de los que estas obras trataban no debían ser abordados por ellas debido a su tan discutida «naturaleza» y el decoro que debían mantener.

Esta situación pudo constituir uno de los motivos por los cuales las mujeres hallaron mayor comodidad en el círculo de lo popular y lo cómico representado por los géneros breves. Otras razones, no obstante, tienen que ver con el gran éxito que tuvieron estas representaciones, así como la adecuada máscara que la comicidad proporcionó a los autores para lanzar críticas que, si bien no pretendían - al menos en el caso de las mujeres- subvertir el orden establecido, sí promovieron un debate sobre los problemas que preocupaban a la sociedad del momento, mostrando su adhesión a una u otra corriente de pensamiento.

Es importante, asimismo, situar la producción de las mujeres en el género breve de mediados del xviıI dentro del contexto de estas representaciones. Aunque es mayor el número de mujeres que se dedicaron a los géneros mayores (Fernández Palacios, 2002), fuera o no desde los preceptos neoclásicos, existieron ejemplos de dramaturgas que, por cuestiones de formación, adhesión al público, etc. escribieron piezas breves.

Es este el caso de la autora María Egual y Miguel (I655-I753) que escribe, además de dos comedias - actualmente no localizadas - , cuatro piezas breves tituladas Coloquio entre Nise y Laura, Coloquio de don Juan y Lizardo, Baile de trajes y Loa; María Antonia de Blancas quien en la misma línea escribe comedias y también sainetes (Sainetillo I y Sainetillo II) como arreglo para la representación de las primeras; Mariana Cabañas y su sainete Las mujeres solas; o algunas de las dramaturgas más conocidas de los géneros breves: Mariana Alcázar (I739-1797) y Joaquina Comella Beyermón (c. I776-c. I80o).

Sea como fuere, es importante destacar que la escritura sigue siendo marginal, pues sigue pesando sobre las mujeres la sombra de la bachillería. ${ }^{\text {II }}$ Si la figura del escritor en el XVIII era todavía bastante precaria y carecía de profesionalización, la realidad de las escritoras era todavía más compleja. ${ }^{\mathrm{I2}}$ La escritura seguía contemplándose para las mujeres como un mero entretenimiento de sus verdaderas tareas. En esta línea, es común encontrar en los prólogos de muchas obras escritas por mujeres una suerte de disculpa ante los posibles defectos, así como una justificación de su escritura, que antecede al texto y que va más allá de una mera captatio benevolentiae:

II Son muchas las investigaciones, más allá del fundacional trabajo de Martín Gaite (1972: 275), que tratan esta cuestión relacionada con los estereotipos femeninos negativos asociados al deseo de aquellas mujeres que buscan una mayor instrucción en el siglo xviıI, fuera de los límites que la sociedad impone y difunde mediante la literatura, la prensa y los diversos tratados pedagógicos de la época (Angulo Egea, 20Ir: 20; Bolufer, 2006: 27r; Establier Pérez, 2006: 182; Urzainqui, 2006a: 292).

I2 Destaca Bolufer (2007) a propósito de esto que quizá la figura que más se asemeja en el siglo XviıI a nuestra idea de escritora moderna es la dramaturga María Rosa Gálvez, cuyo éxito en las tablas le reportó ciertos ingresos, así como gran relevancia pública. 
En el caso de las mujeres, los tópicos acerca de la deseable, necesaria y natural «modestia» de la autora, sus reservas a la hora de comparecer en público y los propósitos siempre «morales» de su obra resultan particularmente intensos y longevos, condicionando la imagen autorial y el eventual relato de su vida. Y el prólogo, más todavía en su caso, aparece como un espacio en el que justificarse, explayarse, anticipar críticas tratando de desarmarlas, solicitar la complicidad del público... Un espacio, en definitiva, en el que afirmar, más o menos veladamente, un yo singular, que tiende a diluirse muchas veces en el resto de la obra [...] (Bolufer, 2008: 38).

Por tanto, su condición de escritora se apuntalaba desde los márgenes y fue este hecho lo que les concedió a muchas autoras una mayor libertad expresiva, abordando temas que distan - e incluso, se contraponen- de aquellos que escribían sus compañeros. ${ }^{\mathrm{I}}$ Pero si, además, sumamos a las categorías marginales de mujer y escritora aquella de actriz, se genera un escenario más complejo donde es posible encontrar, asimismo, matices y características propias de esta intersección.

\section{LAS MUJERES COMO ACTRICES}

No es fácil explicar el largo proceso que el papel de la mujer ha tenido en la historia de la representación teatral. [...] La mujer fue definiendo y evolucionando su postura en la sociedad y en los albores de lo que hoy consideramos teatro moderno, los papeles femeninos se elaboraron como reflejo de esos patrones sociales. Parafraseando la popular frase de la transición, la escena también tuvo que «convertir en normal lo que en la calle ya era normal» (Angulo Egea, 2006: 472).

Si el proceso de profesionalización de la figura del escritor y, por ende, de la escritora presenta grandes dificultades en el siglo XVIII, en no menos espinosos vericuetos se desarrolla el de las actrices. La acepción «actriz» no aparecería definida hasta I830 en el Diccionario crítico-etimológico castellano-hispánico (I984) de Corominas, momento «en que una burguesía moderada desvincula a las mujeres que actúan en los teatros o que cantan en las óperas de la imagen de mujeres casquivanas que bordean la inmoralidad» (Arias de Cossío, 2000: 54). Hasta entonces estas mujeres - conocidas frecuentemente a lo largo de los siglos XVI, XVII y XVIII como «comediantas» y «cómicas» no sin cierto tinte despectivo - se habían visto expuestas a las penalidades económicas fruto de la escasa consideración profesional y a las severas críticas sociales que condenaron su moral mucho más severamente que la de sus compañeros los actores.

En el imaginario social de estos siglos, la imagen de las actrices se asociaba a la de mujeres cuyas vidas se desarrollaban en los márgenes de la moral. Esta vinculación entre las actrices y la falta de moralidad estribaba en el hecho de que estas abandonaron la esfera de lo privado para ocupar la de lo público en las tablas representando, además en muchas ocasiones, el papel de «personajes femeninos que en la mayoría de los casos no eran ejemplos de virtud, se habían abandonado a los placeres pecaminosos» (Arias de Cossío, 2000: 56). Esta consideración peyorativa parece estar relacionada, asimismo, con el hecho de que una de las principales herramientas de trabajo y vehículo expresivo de los actores y las actrices fuera su cuerpo, considerado como algo privado, cuya exposición en

I3 «Son textos singulares concebidos desde esos márgenes, por lo que resulta relativamente fácil, como sucede con La dama misterio, capitán marino encontrar discursos, posturas y reivindicaciones impensables en otros autores, como Trigueros, Iriarte o Moratín, pertenecientes a un entramado político-cultural más o menos influyente» (Angulo Egea, 2OII: I3) 
las tablas podía perturbar al público y levantar «pasiones», cosa que los moralistas trataban de evitar a toda costa (Álvarez Barrientos en Cotarelo y Mori, 2007: 3I). Este tipo de ideas explican el hecho de que surgieran numerosas iniciativas que intentaron prohibir las representaciones teatrales a lo largo de los siglos, especialmente cuando el teatro se afianza como una de las opciones de ocio más consolidadas entre el público. ${ }^{\mathrm{I}}$

Desde el punto de vista de lo económico, la profesión tampoco estaba mejor considerada, por lo que los actores y las actrices tuvieron que ejercer su labor a pesar de las escasas retribuciones económicas y de los obligados viajes que muchos tenían que emprender cuando eran solicitados para representar en la Corte y residían lejos de esta:

En este último punto -el de la dureza y los inconvenientes a que estuvo sometida la situación del actor durante la primera mitad del siglo xviII- escasas diferencias se podían percibir respecto al siglo anterior: sueldos bajos y, a veces, irregularmente abonados — que obligaban a los miembros de las compañías a contraer deudas-, viajes en condiciones penosas y necesidad de conseguir alojamientos en los lugares de representación, eran solo algunos de los inconvenientes habituales en la vida diaria de los cómicos (López, 2000: 289).

No obstante, el calado del ideario ilustrado en España hacia mediados del siglo Xvin se tradujo en una actitud crítica basada en la razón y el reformismo, que se extendió a todos los ámbitos de la cultura y que juzgó a la sociedad del momento como excesivamente conservadora y decadente. Desde este afán progresista se promovieron reformas que afectaron a la educación —en especial, a la de las mujeres—, a los modos de sociabilidad y, por supuesto, a las formas de ocio. En este sentido, el teatro constituyó una de las formas más populares de ocio y, por tanto, una herramienta fundamental de cambio. Así, la intelectualidad ilustrada entendió que el teatro no era solo un espectáculo, sino uno de los principales medios para educar al pueblo en los nuevos valores. Se produjo en este momento un gran debate entre los defensores del teatro barroco, de gusto popular y sin grandes pretensiones didácticas y aquellos que comenzaban a vislumbrar el teatro como escuela moral de costumbres y espejo donde mirarse. Por parte de los segundos, seguidores de la Poética (I737) de Ignacio de Luzán, se darían una serie de esfuerzos de reforma de la escena, sin embargo, no fructificarían hasta la mitad del siglo xvinI, debido a la gran influencia y éxito de la que gozaban todavía las formas del barroco entre el público (Arias de Cossío, 2000: 6I).

En este contexto, se promovieron ciertas reformas teatrales encaminadas a hacer de las tablas no solo un lugar de entretenimiento, sino también un espacio didáctico, lo que influyó en el contenido de las obras y el estilo de actuación. Hasta este momento la formación de actores y actrices tenía como casi exclusiva fuente de recursos el autodidactismo y los modelos de actuación que ofrecía la tradición teatral, así como otros rasgos individuales con mayor valoración por parte del público (gracia, belleza, desparpajo, etc.). Sin embargo, el siglo XviII vivió el aumento de inscripciones de actores en los gremios de representantes y la creación de clases de declamación ${ }^{15}$ por parte de la Junta de Reforma

I4 Por citar solo algunos ejemplos, la crítica a que las mujeres participen en las representaciones teatrales se da ya en el siglo xvi por parte de miembros de clero como el padre Juan de Mariana, que dedica el capítulo octavo de su Tratado contra los juegos públicos a esta cuestión. Esta condena del teatro como algo peligroso continúa inalterada en el tiempo, como evidencia la publicación de la Consulta Theológica acerca de lo ilícito de Representar y ver Representar comedias en España del del clérigo Gaspar Díez en I742 (Arias de Cossío, 200o).

I5 Tratan el tema de la declamación de los actores en el siglo xvin varias investigaciones, entre ellas Álvarez Barrientos (2014) y Soria Tomás (2020). Asimismo, trata por extenso el proceso de la profesionalización del actor en el siglo xviı el último volumen publicado por Álvarez Barrientos (2019). 
de Teatros con las que se buscaba que los profesionales del teatro español estuvieran al nivel de los europeos y, sobre todo, de los franceses.

No obstante, tal y como explica Álvarez Barrientos en su prólogo a la reedición del conocido trabajo de Cotarelo y Mori sobre las Actrices españolas en el siglo XVIII. María Ladvenant y Quirante y María del Rosario Fernández «La Tirana», ${ }^{16}$ estas propuestas reformistas fueron o bien implantadas por obligación o, con frecuencia, hechas sin pensar en los actores, aun a pesar de ser un elemento imprescindible de la escena: «querían dar un nuevo aire a la escena, pero muy poco y tarde se fijaron en la figura del actor, elemento básico para llevar a cabo cualquier reforma en ese ámbito» (2007: 24). Socialmente, la profesión de actor seguía estando escasamente valorada. Si el caso de los actores fue tal, en el caso de las actrices encontramos, de nuevo, una doble forma de marginalización al transitar entre dos categorías interseccionales no privilegiadas: mujeres y actrices:

Los cómicos seguían siendo considerados pecadores que vivían al margen de la sociedad y transgredían todas las normas de la civilización. Las actrices tenían una peor consideración, en tanto que seres cercanos al mundo de la prostitución, aunque fuera bajo la forma de protección de algún noble. Si las mujeres ocupaban un lugar secundario en el imaginario social, las actrices no contaban en el mismo más que como anécdota, aunque pudieran arrastrar a los públicos al teatro (Álvarez Barrientos en Cotarelo y Mori, 2007: 24).

Esta última frase de Álvarez Barrientos sobre el interés que suscitaban las actrices en la audiencia se explica en el siglo XvIII mediante una paradoja. Esta contradicción estriba en la mala percepción que socialmente se tenía de las actrices y, a su vez, la fascinación que estas provocan en el público. ${ }^{17}$ Así, las actrices, mujeres que normalmente pertenecían a clases populares y trabajadoras, fueron acogidas entonces en los famosos salones y tertulias e, incluso, en la Corte. El modelo popular de comportamiento que las actrices proponían, conocido como «majismo», y el desparpajo («el aire de taco») de estas en relación con los hombres, comenzó a moldear también la conducta de las mujeres de la clase alta. Así, tonadilleras como María Antonia Vallejo La Caramba, María Rosario Fernández La Tirana o María Ladvenant supusieron un pilar en la transmisión de los modelos populares que luego imitaría la nobleza tanto en cuestiones de atuendo como de ademanes.

\section{UN CASO DE DOBLE MARGINALIDAD: ESCRITORAS Y ACTRICES}

EN EL PANORAMA TEATRAL DEL XVIII

El recorrido paralelo de los procesos de profesionalización y valoración social de las escritoras y actrices resulta necesario para entender el contexto en el que se desarrollan las obras de Mariana Alcázar, Mariana Cabañas y María de Laborda, objeto de estudio de este trabajo. El caso de estas dramaturgas presenta ciertas particularidades derivadas, precisamente, de la intersección de categorías marginalizadas que las atraviesan, pues no solo son mujeres y escritoras, sino también actrices.

I6 Destaca Álvarez Barrientos en esta reedición del famoso trabajo de Cotarelo y Mori lo peculiar de la elección del objeto de estudio de este. El investigador se centra en las vidas y el desarrollo profesional de dos conocidas actrices precisamente en un momento en el que tanto las categorías de mujer y de actriz siguen siendo consideradas como marginales y meros elementos pasivos de la sociedad. En este sentido, Cotarelo y Mori anticipa en sus investigaciones las tendencias que actualmente gozan de mayor interés (2007: 23).

I7 A este fenómeno le dedica ya en 1792 Martín Gaite el segundo capítulo de sus Usos amorosos del dieciocho en España. Otras investigaciones más recientes han ahondado en esta cuestión: Angulo Egea (2000), López (2000) o Arias de Cossío (2000). 
La Ilustración trajo consigo una serie de cambios que se dejaron sentir en una mayor presencia de las mujeres en las esferas de lo público, incidiendo en la importancia de una educación que les permitiera estar a la altura de los hombres en los nuevos entornos de sociabilidad. No obstante, no todo cambio significó progreso, pues en el caso de las mujeres el nuevo horizonte de posibilidades evidenciaba al mismo tiempo las nuevas limitaciones que estas entrañaban, proponiendo solo una emancipación parcial que, mediante el discurso de la complementariedad de los sexos, terminó por relegar a las mujeres a un papel secundario en la sociedad:

Estas ideas, desarrolladas en los estudios más recientes de historia intelectual, convergen, en cierto sentido, con las interpretaciones formuladas desde hace tiempo, desde la filosofía feminista, por autoras como Celia Amorós o Amelia Valcárcel, para quienes el feminismo fue el «Pepito Grillo» de la Ilustración: una corriente crítica y coherente, pese a su diversidad interna, capaz de poner en evidencia los límites y paradojas del pensamiento ilustrado, al contrastar las posibilidades emancipatorias contenidas en el mismo con la realidad del mantenimiento, la adaptación e incluso el reforzamiento, en los discursos y las prácticas, de las desigualdades entre los sexos, y capaz también, de defender su necesaria superación y, con ella, la realización del verdadero proyecto ilustrado (Amorós, 1997; Amorós y De Miguel, eds., 2005; Valcárcel, 1993; Cobo, 1993; Campillo, 1997) (Bolufer, 2008: 43-44).

Por tanto, cuando estas decidían transgredir en cierto modo el rol que la sociedad había diseñado para ellas, dedicándose a actividades públicas como son la escritura y la actuación, se produce una doble condena social. Como hemos venido desarrollando a lo largo de estas páginas, las profesiones de escritora y actriz no estaban ni socialmente prestigiadas ni adecuadamente remuneradas. Estos obstáculos se sumaron a los problemas derivados de la situación socioeconómica y contexto cultural inherentes a cada una de las autoras.

En este sentido, aunque las investigaciones realizadas extraen acertadamente ciertas características comunes en el perfil de las escritoras del xviII, consideramos necesario matizarlas. Si bien es cierto que estas escritoras se beneficiaron en mayor o menor medida de su cercanía al mundo de la cultura, no todas parecen haber gozado de los privilegios de una educación más esmerada vinculada a las clases altas y a la burguesía comercial de origen extranjero. Es el caso de las dramaturgas cuyas obras nos atañen, pues su formación parece ser el fruto no tanto de un conocimiento puramente intelectual o teórico, sino más bien de carácter práctico, basado en su experiencia en las tablas y el mundo teatral:

Aun cuando el mundo de los cómicos no se destacaba por su profunda cultura, algunos incluso eran analfabetos, eran gente con oficio e imaginación a quien la experiencia cotidiana de las tablas empujó, en ocasiones, a componer algunas piezas dramáticas. Ocurrió con varios reputados actores (Guerrero, Moncín, García Parra...) y sucede igualmente con sus colegas del sector femenino (Palacios Fernández, 2000: II9).

Una de estas actrices-dramaturgas es Mariana Cabañas (Hormigón, 1996: 86, 424; Palacios Fernández, 2002: 224-227). Quien se aproxime al estudio de su figura encontrará de entrada peculiaridades tales como su extracción social popular, su desarrollo como actriz y, probablemente, también como empresaria teatral (Hormigón, I996: 424). El hecho de ser una mujer con un estatus social no privilegiado colocó a Cabañas en una posición ciertamente incómoda para emprender una carrera literaria, algo que supliría 
con un astuto conocimiento de los entresijos teatrales dieciochescos, en los que se había desenvuelto. Pocos son los datos biográficos que se conocen de esta autora más allá de su vinculación con el mundo del teatro y de la autoría de un único sainete titulado Las mujeres solas (1757). Este sainete, representado exclusivamente por mujeres, sirvió de contrapunto cómico a la comedia junto a la que se estrenó, El más justo rey de Grecia de Eugenio Gerardo Lobo (1679-I750), representada con bastante éxito en el teatro de la Cruz el r6 de septiembre de I757 y más tarde el 27 de mayo i769. En la Cartelera de Andioc y Coulon (I996) no se recogen los intermedios de la primera representación, pero sí de la segunda. En esta segunda representación, no figura la obra de Cabañas en los intermedios, por lo que podemos suponer que el sainete debió de ser representado en la primera ocasión (Fernández Palacios, 2002: 226).

Alguna información más se conoce de otra de estas actrices-dramaturgas, Mariana Alcázar Peña (Homirgón, 1996; Emilio Palacios, 2002: 224-227). Aunque nacida en Valencia en I739, gran parte de su vida y carrera literaria se desarrolló en Madrid, ciudad a donde se trasladó en 1757 en busca de un puesto fijo en alguna de las compañías teatrales de la Corte. Allí consiguió un puesto como séptima dama en la compañía de José Parra, momento en el que despegó su carrera como actriz. Conocida ya en el mundo del teatro, se casó con el también actor José García Ugalde, con quien trabajaría en la compañía de José Martínez Gálvez como sexta dama (I760). Su éxito la hizo ascender al papel de graciosa junto a la actriz María Ladvenant en la compañía de la Villa y Corte, dirigida por Ángel Valledón (Díaz Escovar, 5 de marzo de 1919). A razón de su fama entre el público, Alcázar protagonizó fuertes enfrentamientos con la actriz María Ladvenant, enfrentando a los bandos conocidos como los «chorizos», partidarios de la primera, y los "polacos», que apoyaban a la segunda.

[...] María pasa a ocupar el puesto que más ansiaba, el de tercera dama o graciosa, que le permitía actuar con papeles jocosos, pero habría de alternar con la que sería, sin duda alguna, su gran rival y extraordinaria y dotada cómica, Mariana Alcázar, que en el año anterior, con la compañía de Gálvez, había ascendido meteóricamente de sexta a segunda dama. [...] Comenzó entonces un duelo a muerte entre ambas actrices que duró todo el año 176r-62, formándose al tiempo dos bandos o partidos que de manera estrepitosa mostraban en el teatro sus respectivas preferencias por una u otra dama. Y el año siguiente $1762-63$, al formarse las dos compañías, pasó Mariana Alcázar como graciosa, a la compañía de Hidalgo, llamada también la Viuda, y María con igual empleo que la Hidalgo en la de Águeda de la Calle, viuda de Juan Ángel (Peláez, 200o: I43).

En 1762 comenzó a formar parte de la compañía de María Hidalgo como tercera dama. Alcázar decidió en este momento colocar a su hermana Antonia como actriz, pero sus compañeros se opusieron y la Junta decidió multarla y poner vigilancia en su casa. Sin embargo, fue tanta la influencia de esta en el mundo del teatro, que el propio Gobernador habló en su favor en consulta con rey Carlos III, devolviendo el dinero y la libertad perdida a la actriz (Díaz Escovar, 5 de marzo de I9I9). Volvió a los escenarios en I767 y trabajó en distintas compañías hasta que su fama le permitió establecer su propia compañía en Madrid en i77r. Al igual que Cabañas, esta estrenó como dramaturga la única obra que conocemos, La visita del hospital del mundo en torno a los años 1763 o I764 por la compañía de María Hidalgo como preludio a la comedia Adriano en Siria de Antonio Bazo (Hormigón, 1996: 410). Aunque en un primer momento la autoría de este sainete fue atribuida a Ramón de la Cruz (Cotarelo y Mori, 1902), más tarde quedó claro 
que Alcázar era la autora gracias a los manuscritos encontrados, cuyo nombre figura en la portada. Esta obra es un sainete en un acto, escrito en verso y con acompañamiento musical, del que se encuentra copia manuscrita del siglo xIx en el Institut del Teatre de Barcelona. Tras su éxito como actriz, se retiró en I787, año en el que falleció su marido. Ella murió años más tarde el I7 de noviembre de 1797, habiendo gozado del favor de compañeros de profesión como Ramón de la Cruz (Díaz Escovar, 8 de marzo de I9I9).

Las circunstancias vitales de María Laborda, que compartió profesión con las anteriores, son también bastante desconocidas para nosotros. ${ }^{18}$ Se sabe que trabajó como actriz con varias compañías teatrales y que actuó, al menos, en los teatros de Madrid y de Villanueva de los Infantes en Ciudad Real. Asimismo, Laborda procede de similar extracción humilde de Cabañas y Alcázar. Esta creció en una familia de actores, pues compartió oficio con sus dos hermanas (Francisca y Ventura Laborda) según la información de Bordiga Grinstein (2002: 203). Aunque era conocida bajo el nombre artístico de Margarita de Castro, firmó su única obra como Margarita de la Gorda Bachiller. Angulo Egea (20Ir: I2) señala que su pseudónimo (Bachiller) puede connotar cierta ironía en relación con uno de los estereotipos femeninos negativos de la época, tal y como anteriormente hemos abordado. Esta autora, a diferencia de las anteriores, se distanció del género breve, no así del teatro popular. La dama misterio, capitán marino es una comedia en 5 actos, no exenta de muchos de los rasgos populares que se dan en el género del sainete.

Esta obra se encuentra actualmente en la Biblioteca Histórica de Madrid (Tea I-Io7I4) y, aunque se conservan dos apuntes de esta, Bordiga Grinstein (2004: 187-I88) afirma que el A parece ser el original. Por otro lado, aunque el manuscrito no incluye el texto de la censura ni de la licencia, lo que conduce a pensar que la obra no se representó nunca, sí que aparece la firma abreviada de Francisco Cavallés Muñoz «misma firma que aparece en la recensura de I8I7 de la comedia de Gálvez Las esclavas amazonas; y permite especular que la obra de Laborda fue escrita o recensada durante el período en que ejerció este censor» (Bordiga Grinstein, 2002: 203). No obstante, encontramos en la publicación Cartas españolas, o sea revista histórica, cientifica, teatral, artística, crítica y literaria del día 28 de junio de I832 el siguiente apunte sobre la representación de esta obra:

LA DAMA MISTERIO, CAPITÁN MARINO: comedia en cinco actos [...] ¿Quién no diría que un drama titulado La Dama misterio, Capitán marino, no había de excitar una viva curiosidad, aunque mas no fuese que por ser, sino $[s i c]$ de autor conocido, por lo menos de Autora desconocida también, pero que al cabo pertenece al bello sexo, y debía excitar la galantería del público? ... ¡Pero ah! incivil público! ... Poquísimos son los que han acudido al reclamo: las dos representaciones han sonado en hueco, que es una bendición de Dios, y la dialogada novela ha tenido por espectadores como quien dice a los bancos. Es de admirar el candor del cartelista, cuando al ofrecer este drama, entre otras muy lindas cosas, dijo: Al anunciar esta obra dramática, cuyo argumento está tomado de una novela bastante interesante y conocida, no se pretende hacer esperar al público nada perteneciente al género clásico. Y dice muy bien nuestro hombre, porque en resumidas cuentas chay cosa que prometa mejor una comedia clásica que el haberla sacado de una novela? Esto se llama ilación en las ideas. Pero en cambio de esto, y según las luminosas observaciones del cartel, la autora podía obtener la fortuna de elegir y sostener los caracteres, de presentar situaciones agradables y aún dramáticas, y de encontrar benignidad y tolerancia

I8 Algunas referencias a ellas en los catálogos de dramaturgas españolas son las de Hormigón (I996: 261, 585-586) 
de parte del público. No se ha engañado en esto de benignidad y de tolerancia el anunciador; y el reducido público que se ha dejado ver en estas representaciones, ha sido con efecto muy benigno, y muy tolerante... Eso y mucho más obtienen las faldas (pp. 354-355).

Esta nota plantea que no solo parece ser que la obra sí fue representada —al menos en dos ocasiones-, sino que además la fecha de esta representación se sitúa en torno al verano de $1832 .{ }^{19}$ Con respecto al carácter original de la obra, no es esta referencia la única nota que sospecha que la comedia de Laborda podía ser arreglo de alguna otra o versión dramatizada de una novela. Esta hipótesis se explica, en primer lugar, por las características de este texto, que hacen de ella una pieza singular. Sus largos diálogos, así como el desarrollo de los acontecimientos, son mucho más propios del género narrativo que del teatral, en el que se inserta. Por otro lado, la ambientación inglesa de la comedia hace pensar a investigadores como Serrano Sanz (I975, II: I) que esta obra es una traducción. Sin embargo, coincidimos con Angulo Egea (20Ir: I7) cuando sostiene la teoría de que la decisión de situar los acontecimientos fuera de los límites geográficos en los que se desarrolla la propia actriz es una estrategia que le permite alejarse del texto y tratar temas controvertidos como el nuevo papel de las mujeres en la sociedad del xviII, el matrimonio, etc.

Finalmente, importante también en este sentido es la figura y producción teatral de Joaquina Comella, hija del conocido dramaturgo Francisco Comella. Aunque Comella no se encuentra atravesada por las mismas intersecciones que sus compañeras - mujer, actriz y dramaturga- sí que comparte con estas un contexto cultural semejante. Así, el conocimiento sobre el teatro que esta dramaturga poseyó estaba profundamente influenciado por su cercanía con el mundo del espectáculo a través de la figura de su padre. Aunque no existen pruebas que así lo demuestren, muchos investigadores comparten la hipótesis de que Joaquina Comella no solo tuvo el papel pasivo de acompañar a su padre a los distintos coliseos y espectáculos teatrales, sino que también escribió colaborativamente con este algunas de las muchas obras que se le atribuyen a este (Serrano y Sanz, I978: 275; Bordiga Grinstein, 2002: 25; Palacios Fernández. 2002: I96 y 227; García Garrosa, 2015: I28). Los avatares de la vida de esta escritora son, en gran medida, desconocidos más allá de la fecha de su muerte temprana en I80o (Serrano y Sanz, I978). En este desconocimiento ha influido la imagen literaria que se creó de Joaquina Comella, ensombreciendo sus circunstancias vitales reales. ${ }^{20}$ Sobre su labor como dramaturga se sabe con certeza que esta escribió la tonadilla escénica titulada La Anita en I794, aparentemente con tan solo catorce años, y que esta fue representada probablemente en febrero de ese mismo año (Angulo Egea, 1998: 87-88). No obstante, recientemente una nueva investigación de García Garrosa (2015) ${ }^{21}$ ha arrojado nueva luz sobre la producción dramática de esta

I9 Esto plantea una serie de problemas en torno no solo a la datación de los manuscritos, sino también hasta cierto punto acerca de la cronología establecida para la carrera como actriz de María Laborda y su florecimiento como dramaturga. Si bien Bordiga Grinstein (2002) afirma que era ya conocida como cuarta dama de la compañía de Villanueva de los Infantes en I773, el hecho de que la posible primera representación de la obra fuera en I832 nos sitúa en una horquilla cronológica conflictiva con respecto a la trayectoria vital y profesional de esta dramaturga. Consideramos que esta cuestión requiere un análisis más profundo que el que nos permiten estas páginas dedicadas a otra cuestión y, por lo tanto, abordaremos esta problemática en otros trabajos.

20 Angulo Egea (1998) da buena cuenta de esta imagen literaria, cuyo ejemplo más conocido la Doña Mariquita de La comedia nueva de Moratín, inspirado en Joaquina Comella. bidalgo.

2I Además, este trabajo ofrece al lector una edición crítica de una de estas tonadillas titulada La pasiega y el 
autora con el descubrimiento de siete libretos para tonadillas escritas por esta para el compositor Blas Laserna, con quien ya colaborara en La Anita.

En definitiva, podemos afirmar que, aunque con distinta fortuna, estas mujeres tienen en común una serie de características: su extracción humilde, su dedicación al mundo del teatro como actrices y dramaturgas, así como una cierta predilección por lo cómico como vehículo de expresión. Sin embargo, cabría preguntarse si estas similitudes pueden rastrearse asimismo en algún otro aspecto más concreto de sus obras, que las identifique y diferencie del resto de la producción escrita de otras escritoras del siglo xviII.

\section{A PROPÓsito DE LAS MUJERES SOLAS Y LA VISITA DEL HOSPITAL DEL MUNDO}

En las páginas que preceden a este apartado hemos desarrollado cuál es el contexto general en el que desenvuelven las dramaturgas y actrices del xviII. Asimismo, hemos esbozado a grandes rasgos cuáles fueron las circunstancias personales de cada una de estas mujeres, así como su posición en la sociedad. No obstante, por razones no solo de espacio, sino también de adecuación nuestro análisis se centrará exclusivamente en las obras Las mujeres solas de Mariana Cabañas y La visita del hospital del mundo de Mariana Alcázar Peña.

La razón que fundamenta este discrimen del corpus es principalmente el hecho de que estas dos mujeres comparten no solo similares coordenadas histórico-biográficas, sino también que cultivaron el género del sainete. Esta elección no es baladí, sino que responde a una serie de condicionantes relacionados con el género, la formación literaria y la mayor libertad que les concede a estas dramaturgas el hecho de escribir sin la presión del canon que implica la composición de otro tipo de piezas teatrales prestigiadas. Es evidente, asimismo, que el uso del sainete implica necesariamente una determinada temática y desarrollo de personajes, pues son elementos estrechamente vinculados a las convenciones teatrales que los prescriben.

En este sentido, aunque el resto de las actrices-dramaturgas se mueven también en el terreno de lo cómico, géneros como la tonadilla (caso de Joaquina Comella) o la comedia sentimental (género al que puede adscribirse la obra de María de Laborda) poseen características definitorias distintas de las del sainete, por lo que el análisis comparativo entre estos géneros resultaría inadecuado.

Conviene recordar que desde sus inicios el teatro ha supuesto una de las vías más exitosas para la difusión de ideas y discursos que han calado socialmente. En el siglo xviıI donde además el teatro se conforma como una escuela moral de costumbres y espejo en el que reflejarse, este propósito persuasivo se afianza todavía más. En el caso del sainete la función mimética va más allá, pues intenta dar voz a realidades sociales que escapan del canon neoclásico donde no todo es materia teatral:

$\mathrm{Si}$, como subraya Agustín Durán, «la historia reducida a generalidades es ininteligible y estéril porque no puede penetrar el secreto de la clase más numerosa» (xI), los sainetes posibilitan una lectura de esa historia oculta y dan cuenta de la vida cotidiana, de las preocupaciones del momento, del imaginario cultural que está cristalizando. (Díaz Marcos, 2010: 67).

Así, una de las características comunes en los sainetes de Cabañas y Alcázar es, precisamente, el hecho de que estas se centran en su problemática no solo como mujeres, sino específicamente como actrices en el siglo XviII. En ambas obras los personajes femeninos 
actúan como eco de ciertas reivindicaciones de las actrices ante las injusticias que se daban en el terreno de lo teatral.

En el caso de Las mujeres solas esta reivindicación rige la composición de la obra, que se formula como respuesta a la comedia de Lobo junto a la que es representada. El más justo rey de Grecia se precia de ser una comedia en la que las actrices no tienen cabida, representada exclusivamente por hombres. ${ }^{22}$ Para hacer contraste, el sainete de Cabañas señala con orgullo tener en escena únicamente a siete mujeres, todas ellas actrices de la compañía de Parra (Cotarelo y Mori, 1899: 440), que se representan a sí mismas en su diatriba contra los hombres en una suerte de Lisistrata dieciochesca (Doménech Rico, 1996: 7I), aunque con una carga sexual mucho más atenuada y carnavalizada a través de la crítica directa a los hombres en su rol de maridos en un intento de tomar las riendas del asunto.

Antonia, el personaje que lidera la escena, afirma la independencia de las mujeres precisamente en la capacidad que tienen las actrices de desenvolverse en el mundo del teatro sin la ayuda o presencia de los hombres. El reconocimiento de su independencia marcará el inicio del plan de Antonia de ignorar a los hombres, asumiendo el poder y la libertad de sus actuaciones tal y como propusiera el proyecto ilustrado:

Antonia.
Pues, amigas, la experiencia
intentar cualquier cosa,
salir de cualquier empeño,
estado nosotras solas
sin que nos ayuden ellos.
Testigo el caso presente,
pues en él patente vemos
sabemos hacer de hombres
el papel mejor que ellos.
Esto supuesto, y que el daño
que en ellos reconocemos
es juzgarse necesario,
el más seguro remedio,
en que ellos se desengañen,
es el de pasarnos sin ellos,
hacer compañía aparte
y no hacer de ellos aprecio,
no buscarlos para nada,
tratarlos con vituperio,
y aunque os busquen con lisonjas
responderles con desprecios.
Que yo os aseguro, amigas,
que si tomáis mi consejo
y los tratáis de ese modo
que presto han de ser muy buenos.

Antonia explica a sus compañeras las razones por las que ha llegado a la conclusión de que deben olvidarse de los hombres. Además, este personaje ya ha realizado un extenso 
monólogo donde reivindica su independencia a través de la comedia que están representando. Asimismo, emprende una crítica contra los vicios de los hombres tanto casados como solteros, acusándolos de sacar beneficio del matrimonio, de una forma equivalente a las críticas hacia las mujeres que encontraban en el matrimonio una solución para la inestabilidad económico. Para que el plan de Antonia funcione, todas las mujeres — casadas, viudas y solteras - han de participar, reconociendo previamente el estado de dependencia en el que se encuentran. La retórica de la privación de la libertad — bastante recurrente en la tradición teatral- es un hilo conductor en el discurso de las mujeres a lo largo de la obra reforzado a través del léxico con términos como «libertad», «cautiverio», «libres», etc.:

AnTonia.
Porque antes me persuadía
y tenía por muy cierto
que nosotras sin los hombres
no haríamos nada bueno,
y de este error me ha sacado
la comedia que hoy hacemos.
Este motivo me anima,
y el desengaño que tengo
de que todos son ingratos,
desconocidos, soberbios,
presumidos, orgullosos,
muy vanos y desatentos,
falsos como el mismo Judas,
y sobre todo embusteros,
pues a todas nos engañan;
pues ya no se encuentra en ellos,
en los casados amor,
sino el palo, o el despego,
tratándonos como esclavas
y teniéndose por dueños.
Los solteros ya olvidaron
aquel rendido respeto
con que antes nos pretendían,
rompiendo el antiguo fuero
de ser siempre las rogadas
que gozamos tanto tiempo,
pues quieren, desvanecidos,
que les roguemos a ellos,
y no solo que les rueguen
pretenden ya, pero temo
que han de querer que les paguen,
y lo peor será esto.
A lo menos, ya a ninguna
pretenden, sino al dinero,
y en casándose y tomándolo,
yanono, con desprecio.




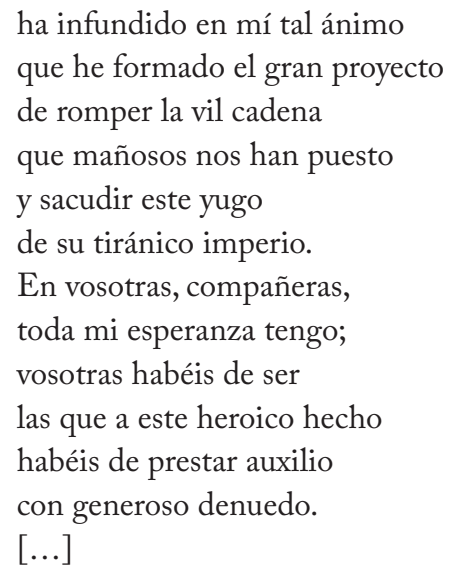

Por otro lado, La visita del hospital del mundo es un sainete que en su estructura simple repite en gran medida el esquema de muchos de los entremeses de finales de los siglos XVI y xviII. En él se presentan una serie de personajes tipo que sirven como medio para la crítica social generalizada de distintos grupos sociales. No obstante, lo interesante en el caso de Alcázar es que de entre esa galería de personajes destaca el mundo de las compañías teatrales y, en especial, el papel de las actrices en este. Una de las enfermas que se presenta ante el doctor es la propia autora, Mariana Alcázar. Sus reivindicaciones se centran en la presión que las actrices tienen con respecto a los requerimientos del público y los vaivenes del gusto de este. A través de sus quejas vislumbra el lector cuáles eran las aptitudes que se esperaban de las actrices del XviII para que estas llenasen el coliseo - versatilidad, habilidad para el canto, gracia natural y desparpajo-, así como también el miedo a opacar las actuaciones de sus compañeros que el éxito de estas generaba.

$\begin{array}{ll}\text { Mundo. ¿Qué enfermos son estos? ¿Cómo, doctor, } \\ \text { Doctor. } & \text { Los males que son internos } \\ \text { la garganta no embarazan. } \\ \text { Petimetra. } & \text { El mío yo le diré } \\ & \text { que el resto no sabe nada. } \\ & \text { Bien ven ustedes, señores, } \\ & \text { que yo soy buena muchacha, } \\ & \text { que canto medianamente } \\ & \text { y que tengo tal cual gracia, } \\ & \text { que no me meto con nadie, } \\ & \text { que mi genio es de una pava. } \\ & \text { Muchos hay que me han querido } \\ & \text { fui de muchos estimada } \\ & \text { y en llegando a tonadillas } \\ & \text { decían que las bordaba: } \\ & \text { que me hayan dejado sola, } \\ \text { ¿acaso es motivo para } & \text { que este hombre tan temerario } \\ \text { alce para mí la tranca? } & \text { Y si no digan ustedes, } \\ \text { ¿le quito yo las entradas? } & \end{array}$




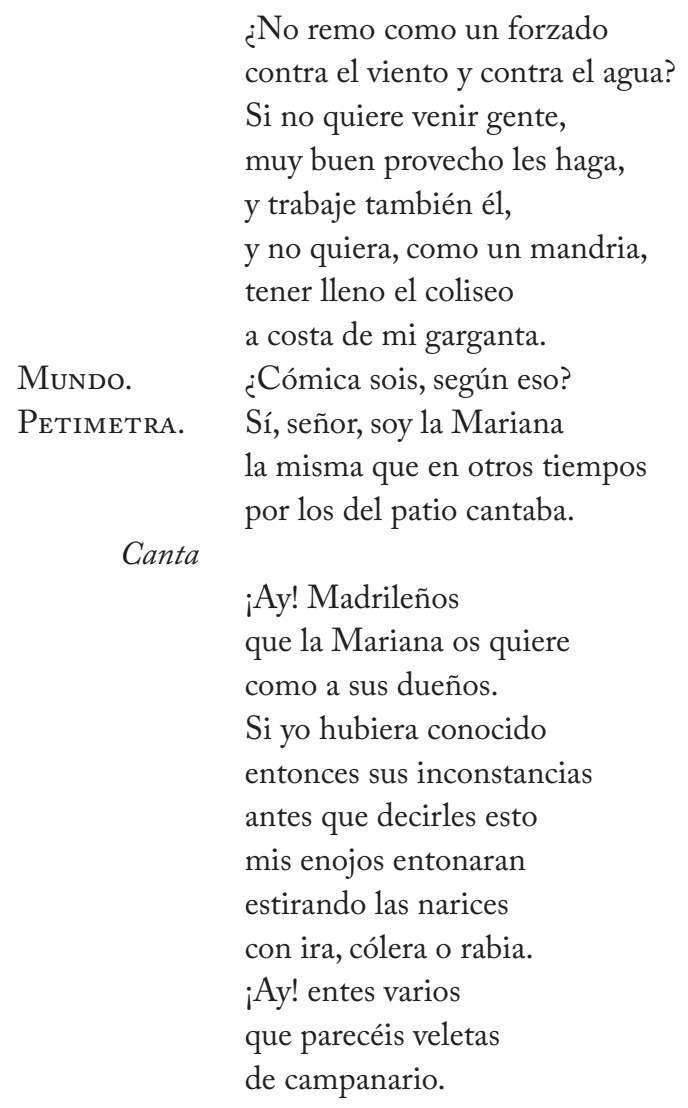

En sus quejas Mariana emplea un léxico similar al de Cabañas que hemos visto en las citas anteriores, que entronca con la retórica de la esclavitud del matrimonio común en muchas otras obras. Vocablos como temerario o mandria se emplean a modo de denuncia de los abusos que se dan por parte de los hombres tanto a nivel laboral como en la propia institución matrimonial. En el caso de nuestras sainetistas el malestar común de las mujeres ante su rol en la sociedad — sujeto al matrimonio y la maternidad — se suma, además, el del escaso reconocimiento y las altas expectativas que pesaban sobre ellas como actrices. La presión sobre estas fue tal que en la mayoría de las ocasiones el éxito o fracaso de una representación recaía en el poder de atracción que esta ejercía sobre el público (López, 2000).

Las actrices y su modo de comportarse dentro y fuera del escenario provocaron la fascinación no solo de las clases populares, sino también de la burguesía y la nobleza que las toma como modelo. Por tanto, lo más interesante que estas podían ofrecer al espectador como contenido teatral son sus propias vivencias

La tonadillera no dejaba de interpretar nunca, era actriz encima del escenario y cuando salía a la calle. [...] Por eso tenían tanto éxito en este tipo de teatro musical breve las historias cuyos protagonistas eran los propios actores con sus problemas; lo público y lo privado se terminaba por fundir en el escenario (Angulo Egea, 2000: 317).

Esto marca otra de las características que tienen en común estos dos sainetes: la construcción de sus personajes femeninos. Todos los personajes de Las mujeres solas y al 
menos los personajes de Mariana, La Paca y Rosalía de La visita del hospital del mundo son actrices que se representan a sí mismas y que forman parte del imaginario de modelos populares de mujeres trabajadoras y, en cierto modo, desafiantes con respecto a los modelos de género que prescriben la sociabilidad de las mujeres. Asimismo, muchos de los personajes de Cabañas (sobre todo Antonia, pero también Mariana, Juana, Mariquita, etc.) y algún otro de Alcázar (Mariana) beben de la tradición teatral que ofrece un modelo de mujer rebelde que, a través de la retórica del yugo masculino denuncia su situación de desigualdad.

Estos tipos femeninos entroncan con estereotipos ya explotados por el teatro áureo como son los de las mujeres guerreras o amazonas, las mujeres marciales, etc. No obstante, estos sainetes actualizan los modelos de acuerdo con la nueva sensibilidad dieciochesca fruto de los profundos cambios que la sociedad burguesa estaba sufriendo sobre todo en lo referente al deterioro de la institución matrimonial, así como en lo laboral. Desde este nuevo prisma, común en otras dramaturgas de la época como la prolífica María Rosa Gálvez (c. I768-1806) en obras como Las esclavas amazonas (I805), las escritoras escenificaron su propia situación a través de los mecanismos que se lo permitían en una diatriba si no en contra de los hombres, al menos sí posicionada en contra de los discursos que las confinaban al hogar y a las tareas secundarias.

García Garrosa afirma a este respecto que la mayor parte de la producción de las mujeres de este período coincide en ser apologética y exhortativa. Esto ocurre en la medida en la que las autoras buscaban que las mujeres conocieran sus obras y que se generara debate en torno a los problemas circunscritos a ellas:

Son apologías escritas no tanto contra los hombres como en respuesta a los hombres, en una especie de diálogo intertextual a tanto escrito masculino que cuestionaba o limitaba a ciertas parcelas el talento femenino, que debatía sobre si la inteligencia tiene sexo, o sobre si se admitía a las mujeres en los ámbitos intelectuales y de poder masculinos (léase las Sociedades Económicas), etc. (García Garrosa, 2007: 209).

Estos modelos de mujeres no fueron bien recibidos por la intelectualidad ilustrada, que mostró un claro rechazo hacia ellos. Quizá esto se deba no solo a razones meramente teatrales, en el sentido de que estos tipos femeninos desafían los preceptos clasicistas en torno al concepto del decoro, sino principalmente — como analiza Díaz Marcos (2010)— a motivos ideológicos, ya que la actitud de estas mujeres cuestionaba implícitamente la autoridad masculina y, por tanto, la concepción canónica de la familia y un determinado orden establecido:

La rebeldía de estas mujeres se percibía, por tanto, como un peligro para la estabilidad de la institución matrimonial - y por extensión de la sociedad al completo- y por eso mismo se convirtieron en el blanco directo de los dardos cómicos y satíricos del sainete (Díaz Marcos, 20Io: 60).

Por otro lado, Fernández Cabezón (2003: 134) explica que el hecho de que obras que presentan modelos de mujeres aguerridas y rebeldes tuvieran tanto éxito se explica por la creciente presencia femenina en los espacios de ocio de la época y el gusto de estas por ver representado en escena todo aquello que no tenía cabida en su realidad. Por lo que, contrario a lo que se espera de las mujeres, estos personajes, amparados en la ficción 
dramática, no temen en expresar sus quejas y arremeter contra el control que ejercen los hombres sobre ellas tanto fuera como dentro del mundo de lo teatral.

$\mathrm{E}$ l tratamiento del matrimonio mal avenido por causa de los gastos asociados a las nuevas costumbres y al concepto de modernidad es común a todos los sainetistas. No obstante, los personajes se perfilan de manera diferenciada en dramaturgos y dramaturgas. Mientras que en sainetes como los de Ramón de la $\mathrm{Cruz}^{23}$ el patrón que se repite es el de las mujeres que responden al tipo de la petimetra manirrota y caprichosa, en las obras de Cabañas y Alcázar - excepto alguna excepción — la frivolidad queda sustituida por la razón y la queja justa de una mujer que contribuye económicamente al hogar. Este discurso que configura una visión de igualdad no es común en otras obras de la época y reflejo, quizá, de las propuestas de la sainetista como actriz. Asimismo, como analiza González Troyano (1990), el tipo del marido austero estaba asociado en los sainetes escritos por de la Cruz a los valores tradicionales del trabajo, que contrastan de manera crítica con los desmanes lujosos de las esposas.

De forma inversa, en el sainete de Cabañas el rol de petimetre es asumido por el marido, que no duda en gastar su dinero en moda mientras impone un límite de gastos a su esposa. Tal inversión de roles, que se sitúa como uno de los núcleos de comicidad de la obra, reutiliza la figura también estereotipada del petimetre no desde la acostumbrada crítica moral de la vanidad y superficialidad masculina, sino desde la perspectiva de la economía familiar. En la visión de la autora las reivindicaciones de los personajes femeninos en el terreno de la política económica del hogar sirven para construir a los personajes masculinos aludidos en la escena. Los personajes femeninos de Las mujeres solas son empleados para reclamar la contribución económica al matrimonio a través del desempeño laboral como actrices. Tales personajes probablemente no solo sirvieron para que las actrices ocuparan los espacios públicos usualmente vedados, sino que se configuran a nivel discursivo como pieza fundamental para el entretenimiento teatral al ser un reclamo para el público. Esto hace que el texto exprese como injusto el sometimiento económico de los personajes femeninos con respecto a sus maridos:

$\begin{array}{ll}\text { Mariquita. } & \text { Pues Felipe, mi marido, } \\ \text { el que tenga compañero } & \text { en esto de gravedad } \\ & \text { y tono de magisterio } \\ & \text { no es posible, y si lo vieras, } \\ \text { entrar en casa muy serio, } & \text { metido a señor de casa, } \\ \text { diciendo muy circunspecto: } & \text { «iEstá todo prevenido? } \\ \text { Cuidado con el gobierno. } & \text { de las cosas, porque mucho, } \\ \text { se me gasta, y yo no puedo } \\ \text { soportar con el partido } \\ \text { a tanto gasto superfluo». } \\ \text { Una cinta no me compra } \\ \text { ni una pluma, ni unos vuelos, } \\ \text { siendo así que como él }\end{array}$

23 Tómese como ejemplo el tratamiento de los personajes femeninos en el sainete La Crítica, la Señora, la Primorosa y la Linda (ca. I780). 


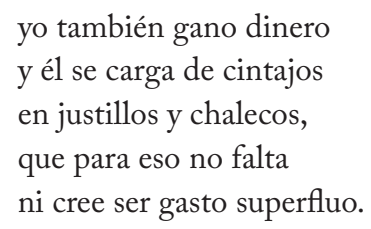

En esta línea, el final del sainete de Cabañas revierte el también clásico escarmiento final típico de estas obras. En el caso de Ramón de la Cruz, Ignacio González del Castillo y otros sainetistas el broche final del sainete suele responder al esquema de la mujer que es reprendida por sus comportamientos rebeldes, arrepintiéndose de sus actos y asegurando el status quo (Díaz Marcos, 2010: 58). No obstante, en Las mujeres solas nuevamente el tópico queda invertido al ser los personajes masculinos, exclusivamente aludidos en el transcurso de la obra, en quienes recae la penalización moral derivada del juicio a sus costumbres. Los actantes femeninos, encabezados por el personaje de Antonia, se dirigen al patio - lugar habitual para el público masculino-, con una suerte de listado de los insultos y defectos que les recriminan. Por tanto, si fijamos nuestra atención, muchos de estos vicios se corresponden con aquellos que la tradición asociaba al género femenino; nos referimos, por ejemplo, a adjetivos como «necios», «vanos», «presumidos» $\mathrm{o}$ «majaderos» en una subversión — que no transgrede el cercado ficcional del terreno teatral- de los roles de género asignados a los hombres y las mujeres en el siglo xviII:

\begin{tabular}{|c|c|}
\hline Antonia. & Y que conozcan los hombres (Al frente, al patio) \\
\hline & que por locos, \\
\hline Mariquita. & que por necios, \\
\hline JUANA. & por vanos, \\
\hline María Teresa. & por presumidos, \\
\hline MARIANA. & por tontos, \\
\hline Micaela. & por majaderos, \\
\hline FRASQUita. & por altivos, \\
\hline Antonia. & orgullosos, \\
\hline MARIQUITA. & desvanecidos, \\
\hline JUANA. & soberbios, \\
\hline María Teresa. & por poco finos, \\
\hline MARIANA. & por falsos, \\
\hline Micaela. & desatentos, \\
\hline FRASQUITA. & y groseros \\
\hline Antonia. & han perdido nuestra gracia, \\
\hline MARIQUitA. & que nos separamos de ellos, \\
\hline JUANA. & que no los necesitamos, \\
\hline María Teresa. & que sin ellos pasaremos, \\
\hline MARIANA. & que ya el verlos nos enfada \\
\hline Micaela. & y que aun yo los aborrezco. \\
\hline
\end{tabular}

Una visión similar es la que ofrece el sainete de Mariana Alcázar. Aunque en este caso el personaje del marido no se construye bajo el estereotipo del petimetre, sí que es empleado de igual modo para exponer los abusos económicos cometidos por los maridos sobre las esposas, amparados en la institución matrimonial, que desposeía a las mujeres de sus bienes (Pascua Sánchez, 2016). En este sentido, uno de los conflictos que se desarrollan en La visita del hospital del mundo aborda la presión sobre las actrices cuyas actuaciones 
dejan de tener éxito, pues tal imprevisto laboral repercute no solo en la estabilidad económica sino en su posición dentro del matrimonio. Esto se manifiesta en la escena mediante la intención del personaje del marido de la actriz de castigar físicamente a su esposa por su escaso rendimiento económico. La queja, por tanto, se construye desde una posición en común con la de la obra de Mariana Cabañas, a saber, que los hombres solo están interesados en el matrimonio con las actrices siempre que este enlace les proporcione beneficios económicos, sufriendo las consecuencias cuando este deja de ser el caso.

$\begin{array}{ll}\text { Doctor. } & \text { ¿Qué motivo tenéis vos, } \\ \text { decid, para maltratarla } & \\ & \text { y traerla a aqueste hospital } \\ \text { cuando el mal que tiene es nada? } & \text { ¿Cómo que no? ¿Puede ser } \\ \text { MARido. } & \text { enfermedad más tirana } \\ & \text { que la que el comer nos quita? } \\ & \text { Y pues antes a escucharla } \\ & \text { venían, y ahora no vienen, } \\ & \text { sin duda que ella es la causa; } \\ & \text { con que así, o dadla un remedio } \\ & \text { o dejad despachurrarla. }\end{array}$

Aunque las quejas en torno a los problemas que se generan en el matrimonio resultan comunes en muchas de las obras tanto de dramaturgas como de dramaturgos - con matices diferenciadores-, lo particular en el caso de estas dramaturgas-actrices es que estas quejas se articulan en el terreno de lo económico.

Encontramos esta reivindicación como otra de las características comunes a estas sainetistas e inherente a su propia experiencia. Cabe apuntar con respecto a tal cuestión que para proteger la moral de las actrices de la crítica de la sociedad se impuso la práctica de casarlas tan pronto como fuera posible con actores de su misma u otra compañía de teatro. Además, como explica López (2000: 290), el matrimonio entre actores era prácticamente la única opción para las actrices, cuya deteriorada reputación podía llegar a impedir su casamiento con cualquier otro hombre. Esta unión no solo implicaba una mejora de la imagen moral que proyectaban estas mujeres, sino que también traía consigo aquellas limitaciones de las que algunas autoras — caso de Cabañas y Alcázar- dan cuenta, sobre todo en lo referente a la falta de autonomía económica:

Si bien muchas se identificaron de forma entusiasta con los modelos de maternidad y conyugalidad sensible, otras, en cambio, aun admitiendo el papel doméstico de las mujeres, no idealizaban sus responsabilidades y sus funciones, sino que admitieron el malestar en lo privado, es decir, la profunda desigualdad que atravesaba el orden moral y sentimental (además de económico y jurídico) de la familia, y reclamaron la posibilidad de realizar otras expectativas (Bolufer, 2008: I35).

Así, uno de los temas que más ha llamado la atención de las historiadoras feministas en el estudio de las relaciones conyugales es el poder, entendido en sentido amplio no solo como la autoridad por parte de entidades formales, sino también de las tensiones y desequilibrios que se dan dentro de la pareja y en las relaciones con otros. De esto deriva otro punto esencial que la historiografía anglosajona ha venido llamando agency y se resume en la capacidad de toma de decisiones de las mujeres sobre aspectos relativos a sus propias vidas y relaciones. 
En este sentido, el mayor poder en una relación se otorgaba al hombre. Sin embargo, en las clases sociales altas y burguesas las mujeres formaban parte necesaria del entramado de las relaciones familiares, ya que su patrimonio y linaje se usaba como garantía de estabilidad económica matrimonial (Bolufer y Morant, 2009). A este caso de mujeres con cierta prestancia en el desarrollo económica de la unidad familiar podemos añadir además el de la situación de las actrices, con el importante matiz de su extracción social. Aunque estas formaban parte de las clases populares, su influencia en la sociedad del siglo XviII, así como su presencia en muchos espacios de la élite intelectual las convertía en piezas fundamentales del engranaje económico que sustentaba el funcionamiento de las compañías teatrales. Por ende, estas mujeres quizás pudieron ser conscientes de su situación privilegiada dentro del matrimonio como parte económicamente contribuyente y así manifestaron su situación de dependencia de sus maridos como injusta, ya que las desproveía de una autoridad sobre el capital familiar a merced de la gestión, no siempre consensuada, de sus cónyuges.

\section{Conclusión}

A lo largo de estas páginas hemos querido desarrollar un contexto que englobe la producción dramática de un grupo determinado de escritoras atravesadas por una serie de categorías marginales en el contexto en el que se desenvolvieron. Como mujeres, escritoras y actrices estas tuvieron dificultades para obtener aceptación social. La escasa valoración y la imagen peyorativa que circundaba a las mujeres que ocupan los espacios de lo público implicó, asimismo, la imposibilidad de alcanzar cierta notabilidad en el desarrollo de unos oficios que todavía carecían de profesionalización.

Este trabajo pretende relacionar unos textos que no han despertado excesivo interés por parte de la comunidad científica, ya sea por la escasa atención que se ha prestado históricamente a las obras de estas mujeres o de los prejuicios en torno a la importancia literaria de los géneros breves (Palacios Fernández, 2002; Bordiga Grinstein, 2002; Bolufer, 2006, 2009, 2014a; Álvarez Barrientos, 2008; Romero Ferrer, 2008). Es cierto que estas piezas teatrales no poseen gran valor literario en términos de recursos dramáticos o influencia en la posteridad de las letras. No obstante, consideramos que estas obras gozan de gran valor documental para la investigación. Así pues, su análisis nos ofrece claves para comprender el contexto en el que las actrices del xviII desarrollaban su carrera o, cuanto menos, cuál es la visión que estas ofrecían al mundo desde el punto de vista de la ficción. En este punto es necesario matizar que, por tanto, no podemos abordar el análisis de los textos literarios como un reflejo verosímil de la realidad:

El estudio de las normas morales, modelos normativos e imágenes literarias conlleva siempre una pregunta latente: ¿hasta qué punto y de qué formas hicieron suyos las mujeres y hombres de la época los modelos propuestos y difundidos por la literatura normativa y de creación? Es esta una cuestión crucial que alude a la circulación entre imágenes culturales y experiencias de vida, a las apropiaciones individuales y colectivas de los modelos (Bolufer, 2008: 3I).

Así, consideramos que, aunque las reivindicaciones expresadas en los discursos de los personajes femeninos pudieran no traspasar el plano de lo teatral, sí que evidenciaban el malestar de las mujeres desde su experiencia como actrices hacia los discursos de feminidad que la sociedad dieciochesca fue encargándose de difundir.

Tal malestar se articula, según nuestro análisis, en una reevaluación de la estructura económica de la unidad familiar. El matrimonio, que venía impuesto como medida social 
para garantizar la protección jurídica y el desarrollo de la carrera profesional de estas mujeres, resulta no obstante ineficaz a la hora de proporcionar a las actrices la independencia suficiente para gestionar su trabajo. Solo así podemos contextualizar los discursos objeto de nuestro análisis en torno al matrimonio como un estado de servidumbre y lastre para el progreso laboral de las actrices. Dicha crítica supuso un revés a uno de los núcleos del orden social ilustrado, como fue la institución de la familia en torno a una autoridad masculina.

El riesgo derivado del cuestionamiento de estas ideas que la élite social en general avala subsume a estas dramaturgas y actrices en un estado de periferia cultural. Este alejamiento de lo canónico, no obstante, garantiza una cierta libertad creativa a estas mujeres para llevar a los escenarios - en el feliz caso de conseguir representar- obras en las que se desarrolla un discurso que propone una alternativa a la economía familiar. Quizá se podría vincular la escasa atención que la intelectualidad de la época prestó a estas mujeres en contraposición con el éxito que algunas de ellas alcanzaron (como Mariana Alcázar) a la mayor o menor adhesión de las clases sociales a estas propuestas. Esto podría deberse a que entre las clases populares, donde la división del trabajo entre los hombres y las mujeres, era frecuente, una reconfiguración de las relaciones de dependencia establecidas en la institución matrimonial contara con mayor apoyo.

En suma, la intersección de las categorías «mujer», «actriz» y «dramaturga» produce una serie de discursos cuyo interés radica en las tensiones que se generan en el seno de la familia y el matrimonio dieciochescos. Tales discursos confluyen en las obras de autoras que, si bien se hallan en coordenadas distintas, comparten similares perspectivas acerca de su desarrollo profesional tanto en el terreno de la actuación como de la creación.

\section{Bibliografía}

AlCázar, Mariana, La visita del hospital del mundo. Entremés o sainete de -, Manuscrito del siglo XIx, Barcelona, Institut del Teatre, Sig. 47.176.

Álvarez BARRientos, Joaquín (2008), «Acerca de la historiografía sobre el teatro breve del siglo xviII. La musa y la crítica castizas como defensoras de la patria amenazada», en Joaquín Álvarez Barrientos y Begoña Lolo (eds.), Teatro y Música en España: los géneros breves en la segunda mitad del siglo ХVIII, Madrid, Universidad Autónoma de Madrid-CSIC.

Andioc, René (1976), Teatro y sociedad en el Madrid del siglo XVIII, Madrid, Fundación Juan March/ Castalia.

— y Coulon, Mireille (I996), Cartelera teatral madrileña del siglo XVIII (I708-1808), Anejos de Criticón.

Angulo Egea, María (1998), «Una tonadilla escénica. “La Anita” de Joaquina Comella, con música de Blas de Laserna», Salina: revista de lletres, ${ }^{\circ}$ I2, pp. 76-90.

- (2000), «María Pulpillo: los problemas de una cantatriz del siglo xviII», en Luciano García Lorenzo, Autoras y Actrices en la historia del teatro español, Murcia, Universidad de Murcia, pp. 309-327.

- (2006), «Virtuosa, casta y heroica. La mujer española en el melólogo del xvıI»», Revista de Literatura, ${ }^{\circ}{ }^{\circ} 36$, pp. 47- 488 .

- (20II), «Hombre o mujer, cuestión de apariencia. Un caso de travestismo en el teatro del XviII", Anales, no 23, pp. II-34.

Arias de Cossío, Ana. María (2000), «La imagen de la actriz en España», Boletín de Arte, nº 2I, pp. $53^{-7} 78$. 
Bolufer Peruga, Mónica (2005), «Transformaciones culturales: Luces y sombras», en Isabel Morant Deusa (dir.), Historia de las mujeres en España y América Latina, vol. 2: El mundo moderno. España y América colonial, Madrid, Cátedra, pp. 479-510

- (2006), «Las mujeres en la España del siglo Xvin: trayectorias de la investigación y perspectivas de futuro», en Susana Gil Albarellos-Peréz Pedrero y Mercedes Rodríguez Pequeño (eds.), Ecos silenciados: la mujer en la literatura española, siglos XVII al XVIII, Valladolid, Junta de Castilla y León, pp. 271-288.

- (2007), «Mujeres de letras. Escritoras y lectoras del siglo XviıI», en Rosa María Ballesteros García y Carlota Escudero Gallegos (eds.), Feminismos en las dos orillas. Málaga, Universidad de Málaga, pp. II3-I42.

- (dir.) (2008), Mujeres y modernización: estrategias culturales y prácticas sociales (siglos $X V I I I-X X)$, Madrid, Instituto de la Mujer.

- (2009), «Persiguiendo un sujeto esquivo: vida y obra de una escritora del siglo XVIII», en Manuel-Reyes García Hurtado (ed.), La vida cotidiana en la España del siglo XVIII, Madrid, Sílex, pp. I55-I80.

- y Morant Deusa, Isabel (2009), «Mujeres y hombres en el matrimonio. Deseos, sentimientos y conflictos», en Cristina Borderías (ed.), La historia de las mujeres: perspectivas actuales, Barcelona, Icaria Editorial, pp.I33-162

- (20I4a), «Modelar conductas y sensibilidades: un campo abierto de indagación histórica», en Mónica Bolufer, Carolina Blutrach y Juan Gomis (eds.), Educar los sentimientos y las costumbres: una mirada desde la Historia, Zaragoza, Institución Fernando el Católico, pp. 7-18.

- (20I4b), «Sociabilidad mixta y civilización: miradas desde España», en Mónica Bolufer, Carolina Blutrach y Juan Gomis (eds.), Educar los sentimientos y las costumbres: una mirada desde la Historia, Zaragoza, Institución Fernando el Católico, pp. I49-I74.

Bordiga Grinstein, Julia (2002), «Panorama de la dramaturgia femenina española en la segunda mitad del siglo xviII y principios del siglo XIX», Dieciocho: Hispanic Enlightenment, n 25.2, pp. $195^{-218 .}$

- (2004), «La dama misterio, capitán marino, una heroína de la Ilustración disfrazada de varón», Dieciocho: Hispanic Enlightenment, no 27.I, pp. 195-218.

Cabañas, Mariana, Saynete para la comedia El más justo rey de Grecia; Las mugeres solas. De la Sra., Manuscrito del siglo Xviı, Barcelona, Institut del Teatre, Sig. CDLXXX-ıo.

Cantos Casenave, Marieta (2009), «Sociabilidad doméstica y sociabilidad pública a través de la literatura dieciochesca», Cuadernos de Ilustración y Romanticismo, no 8, pp. 29-39.

Cotarelo y Mori, Emilio (2007), Actrices españolas en el siglo XVIII. María Ladvenant y Quirante y María del Rosario Fernández «La Tirana», Madrid, Publicaciones de la Asociación de Directores de Escena de España.

Crenshaw, Kimberlé (1989), Demarginalizing the Intersection of Race and Sex: A Black Feminist Critique of Antidiscrimination Doctrine, Femninist Theory and Antiracist Politics, Chicago, University of Chicago Legal Forum.

Díaz Escovar, Narciso (5 marzo, I9I9), «Antiguallas escénicas valencianas I. Mariana Alcázar», Las Provincias: Diario de Valencia, Año LIV, no I6263.

— (8 de marzo de I919), "Antiguallas escénicas valencianas II. Mariana Alcázar», Las Provincias. Diario de Valencia, Año LIV, n 16266.

Díaz Marcos, Ana María (2010), «Mujeres de genio amargo: La crisis matrimonial en los sainetes de Ramón de la Cruz», Confluencia: Revista hispánica de cultura y literatura, $\mathrm{n}^{\circ}$ 25.2, pp. 56-69.

Doménech Rico, Fernando (ed.) (I996), Teatro breve de mujeres (siglos XVII-XX), Madrid, Asociación de Directores de Escena de España. 
Establier Pérez, Helena (2006), «Una dramaturgia feminista para el siglo xviı: las obras de María Rosa Gálvez de Cabrera en la comedia de costumbres ilustrada», Dieciocho: Hispanic Enlightenment, $\mathrm{n}^{\mathrm{o}} 29.2$, pp. 179-204.

Establier Pérez, Helena (2015), «María Martínez Abello y la «comedia nueva» de entresiglos en clave femenina: Entre los riesgos de amor, sostenerse con honor. La Laureta (I80o)», Dieciocho: Hispanic Enlightenment, no 38.1 , pp. I25-I52.

Fernández-Cortés, Juan Pablo (20I7), «Vidas divergentes. Mujeres en la escena musical madrileña del siglo XvıIı", Revista de musicología, no XL.2, pp. 6o9-6I6.

Franco Rubio, Gloria Ángeles (2007), «La contribución literaria de Moratín y otros hombres de letras al modelo de la mujer doméstica», Cuadernos de Historia Moderna. Anejos, no vi, pp. 22I-254.

García Garrosa, María Jesús (2004), «En los inicios de la comedia neoclásica: La aya, de María Rita de Barrenechea (I750-I795). Estudio y edición», Cuadernos de Estudios del Siglo XVIII, $\mathrm{n}^{\mathrm{o}} \mathrm{I} 4, \mathrm{pp} .25-66$.

- (2007), «La creación literaria femenina en España en el siglo xviII: un estado de la cuestión», Cuadernos de Historia Moderna. Anejos, n 6, pp. 203-219.

- (2015), «Joaquina Comella, autora desconocida de los libretos para siete tonadillas de Blas de Laserna», Cuadernos dieciochistas, n I6, pp. 125-163.

García Hurtado, Manuel (ed.) (20I6), El siglo XVIII en femenino. Las mujeres en el siglo de las luces, Madrid, Editorial Síntesis.

García Lorente, Luciano (ed.) (2000), Autoras y actrices en la bistoria del teatro español, Murcia, Universidad de Murcia.

González Troyano, Alberto (I990), «Teatro y cultura popular en el siglo XviII», Draco, nº 2, pp. 193-2II.

Gronemann, Claudia (2006), «El ideal de la «mujer culta» en los discursos del siglo xvinI. Desmontaje de un estereotipo cultural», en Susana Gil Albarellos-Peréz Pedrero y Mercedes Rodríguez Pequeño (eds.), Ecos silenciados: la mujer en la literatura española, siglos XVII al XVIII, Valladolid, Junta de Castilla y León, pp. 397-409.

Hormigón, Juan Antonio (dir.) (1996), Autoras en la Historia del Teatro Español (150o-1994), Madrid, Publicaciones de la Asociación de Directores de Escena de España.

López, Alicia (2000), «Las virtuosas cortesanas en los Reales Sitios», en García Lorenzo, Luciano, Autoras y Actrices en la historia del teatro español, Murcia, Universidad de Murcia, pp. $287-308$.

López-Cordón Cortezo, María Victoria (2005), «La fortuna de escribir. Escritoras de los siglos XVII y XVIII», en Isabel Morant Deusa (coord.), Historia de las mujeres en España y América Latina, Madrid, Cátedra, vol 2, pp. 193-234.

- (2006), «Ejercicio literario y tópicos ilustrados en la obra de Josefa Amar y Borbón», en Susana Gil Albarellos-Peréz Pedrero y Mercedes Rodríguez Pequeño (eds.), Ecos silenciados: la mujer en la literatura española, siglos XVII al XVIII, Valladolid, Junta de Castilla y León, pp. 359-386.

- (20I6), «El espejo palatino o la malla de las damas: ¿`sociabilidad cortesana o cultura política?», en Manuel García Hurtado (ed.), El siglo XVIII en femenino. Las mujeres en el siglo de las luces, Madrid, Editorial Síntesis, pp. 79-1o6.

McCall, Leslie (2005), «The Complexity of Intersectionality», Signs: Journal of Women in Culture and Society, $\mathrm{n}^{\mathrm{o}} 3 \mathrm{O} \cdot 3$, pp. $\mathrm{I} 7 \mathrm{I}^{-\mathrm{I}} 8 \mathrm{OO}$. 
Morant Deusa, Isabel (2003), «Las mujeres en los espacios del saber ilustrado. Algunas trayectorias y tensiones», en María José de la Pascua Sánchez y Gloria Espigado Tocino (eds.), Frasquita Larrea y Aherán. Europeas y españolas entre la Ilustración y el Romanticismo (I750-I850), Cádiz, Universidad de Cádiz, pp. 55-8I.

Palacios Fernández, Emilio (2000), «Noticia sobre el parnaso dramático femenino en el siglo XviıI», en Luciano García Lorenzo, Autoras y Actrices en la historia del teatro español, Murcia, Universidad de Murcia.

- (2002), La mujer y las letras en la España del siglo XVIII, Madrid, Ediciones Laberinto.

- (2006), «Panorama de las escritoras del siglo Xviı», en Susana Gil Albarellos-Peréz Pedrero y Mercedes Rodríguez Pequeño (eds.), Ecos silenciados: la mujer en la literatura española, siglos XVII al XVIII, Valladolid, Junta de Castilla y León, pp. 335-358.

Pascua Sánchez, María José de la (20I6), «Vivir en soledad, vivir en compañía: las mujeres y el mundo familiar en el siglo xviı hispánico», en Manuel-Reyes García Hurtado (ed.), El siglo XVIII en femenino. Las mujeres en el siglo de las luces, Madrid, Editorial Síntesis, pp. I5I-I84.

Peláez Martín, Andrés (2000), «María Ladvenant y Quirante: primera dama de los teatros de España, en Luciano García Lorenzo (ed.), Autoras y Actrices en la historia del teatro español, Murcia, Universidad de Murcia, pp. I33-I54.

Romero Ferrer, Alberto (2008), «El sainete y la tonadilla escénica en los orígenes del costumbrismo andaluz», en Joaquín Álvarez Barrientos y Begoña Lolo (eds.), Teatro y Música en España: los géneros breves en la segunda mitad del siglo XVII, Madrid, Universidad Autónoma de Madrid-CSIC, pp. 237-364.

Serrano y Sanz, Manuel (1975 [1903]), Apuntes para una biblioteca de escritoras españolas (desde I4OI al I833), BAE, Vols. 269 y 270, Madrid, Ediciones Atlas.

Soria Tomás, Guadalupe (2020), «El saber del actor español en el siglo XviII. La expresión de las pasiones en los tratados de declamación», Cuadernos de Estudios del Siglo XVIII, no 30 , pp. 567-592.

Urzainqui Miqueleiz, Inmaculada (2006a), «La mujer como receptora literaria en el siglo xviıI», en Susana Gil Albarellos-Peréz Pedrero y Mercedes Rodríguez Pequeño (eds.), Ecos silenciados: la mujer en la literatura española, siglos XVII al XVIII, Segovia, Junta de Castilla y León, pp. 299-3ㅍ.

- (2006b), «Catalin» de Rita de Barrenechea y otras voces de mujeres en el siglo XVIII, VitoriaGasteiz, Ararteko.

- (2016), «La prensa española como modeladora de la conducta femenina», en ManuelReyes García Hurtado (ed.), El siglo XVIII en femenino. Las mujeres en el siglo de las luces, Madrid, Editorial Síntesis, pp. 308-321.

Vega Toscano, Ana (2016), «La música en el espacio femenino del siglo xviII español», en Manuel-Reyes García Hurtado (ed.), El siglo XVIII en femenino. Las mujeres en el siglo de las luces, Madrid, Editorial Síntesis, pp. 293-303.

Zorrozúa Santisteban, María Pilar (I998), Escritoras de la Ilustración española (I759-I808), Tesis doctoral, Universidad de Deusto. 